\title{
MATERIAL FLOW OPTIMIZATION - A CASE STUDY IN AUTOMOTIVE INDUSTRY
}

\author{
Jolanta B. Krolczyk, Grzegorz, M. Krolczyk, Stanislaw Legutko, Jerzy Napiorkowski, Sergej Hloch, \\ Joachim Foltys, Ewelina Tama
}

Original scientific paper

Today, most contemporary organisations are facing many dilemmas, the essence of which is the determination of the ways of acquisition or maintenance of their position in the competitive environment. Companies have to continuously increase their economy. One of the ways to get competitive prevalence is analysis and optimization of material flow which contributes to the reduction of the company costs. Material flow in a production organization tells us a lot about how well the system is organised. The paper presents an analysis of the current state of material flow in a production company of the automotive branch. A project of the material flow optimization has also been proposed; the project consists of creation of a program of internal transport and optimization of the location of the working stands. The paper describes the current problems of the company internal transport and indicates solutions to those problems.

Keywords: automotive industry; company logistics; material flow analysis; optimization; program of internal transport

Optimizacija toka materijala - analiza slučaja u industriji motornih vozila

Izvorni znanstveni članak

Danas je većina organizacija suočena s mnogim dilemama, bit kojih je određivanje načina postizanja ili održavanja stečenog položaja u konkurentnom okruženju. Poduzeća moraju neprestano povećavati svoju ekonomiju. Jedan od načina stjecanja nadmoći nad konkurencijom je analiza i optimizacija toka materijala, što doprinosi smanjenju troškova. Tok materijala u proizvodnoj organizaciji govori nam mnogo o organizaciji sustava. U radu se daje analiza postojećeg stanja toka materijala u jednoj proizvodnoj organizaciji motornih vozila. Predlaže se i projekt optimizacije toka materijala; projekt se sastoji od novog programa internog prijevoza i optimizacije položaja radnih štandova. U radu se opisuju postojeći problemi u internom prijevozu poduzeća i daju rješenja tih problema.

\section{Ključne riječi: analiza toka materijala; industrija motornih vozila; logistika poduzeća; optimizacija; program internog prijevoza}

\section{Introduction}

Today, most contemporary organisations are facing many dilemmas, the essence of which is the determination of the ways of acquisition or maintenance of their position in the competitive environment [1]. Companies have to continuously increase their economy due to the ever tougher domestic and international competition of companies and due to the transition from the market of vendors to the market of purchasers. Goals of the market and goals of the company affect economy [2]. Starbek and Menart [2] present, in the form of graph, systems of goals for maximising economy. According to the authors, the goal of a company is to achieve steady and even use of its production resources with minimum state of material while the market requires short flow times and assured fulfilment of the terms agreed [2]. The way to maximising economy is to reduce warehouse costs, bound capital, flow times, delay costs, delivery terms and increase readiness for delivery.

Processes convert materials from one form to another adding value to them. Thus, the objective of a manufacturing company is to add value and to do so in the most efficient way, with the least amount of waste in terms of time, materials, money, space and labour. To increase productivity, the processes and operations need to be properly selected and arranged to permit smooth and controlled flow of material through the factory. The more efficiently materials can be produced and converted into the desired products that function with the prescribed quality, the greater will be the companies' productivity and the better will be the standard of living of the employees [3].

The main fault of companies is a too high net cost of product which leads to incompetitiveness. Irrational production can be a result of poorly organized material flow. Material flow in a production organization tells us a lot about how well the system is organized. It also gives us a pretty clear image of the quality and knowledge of the technological preparation department, thus it is vital for a company to employ an engineer who can design and operate an efficient manufacturing system [2, 3]. Starbek and Menart [2], in their research of optimization of material flow in production, have found that too high net cost is a result of irrational material flow and of the fact that workpieces remain too long in the production process (excessive flow times). Proper material flow results, too, in less non-technological production operations. Those additional operations do not alter the qualitative properties of the workpieces (mechanical, chemical, electric, shape). However, they do contribute considerably to the net cost. Since those additional operations are in fact unproductive and unpaid ones, they have to be reduced to a minimum.

Material flow analysis (MFA) has become a useful tool for many aspects and issues of human activity. The utilization of MFA results differs significantly between industry and regional analysis. For the first time, the method of material flow analysis was applied by Wolman [4] to study the metabolism or physiology of cities. Since then, MFA has been applied to understand such systems as densely populated regions in developed countries [5]. MFA has also been used to trace pollutants [6]. In industry, MFA results have been quite successfully used for optimizing material flows and waste streams in production processes. The notion of MFA is based on the idea of optimizing within various industry sectors [7 : 11]. Recently, much research is carried on concerning material flow in many branches, such as: ceramics [12], steel [13, 14], automotive [1], environment and ecology 
$[15 \div 19]$ at the regional and global level. MFA has become a useful tool, especially for industrial ecology (IE), to analyse the metabolism of social systems, such as countries and regions. Sendra et al. [20] used the indicators derived from MFA, complemented with water and energy indicators, to analyse the efficiency and materialization ranks of industrial areas located in Catalonia (Spain). At a regional scale, MFA results could be applied as follows: (i) to derive measures for improving the regional or corporate management of materials, (ii) to set up monitoring programs to evaluate the effects of policy measures, (iii) as a tool for early recognition of the impact of different scenarios of socioeconomic development [21]. MFA can help to identify the major changes in material flows. Thus, as we can notice, MFA is a tool to evaluate the existing systems of food production, transportation and other important human needs, as well as to support the design of new, more efficient systems [22].

Mechanization of internal transport is an important factor in many industrial companies, to a significant extent determining the organization of production and its costs. Optimization of the transport paths and selection of transport devices are factors making it possible to reduce the manufacturing cost. Material flow diagram, including Sankey diagram, should be the indispensable basis of analyses and assessment of internal transport. The Sankey diagram is an important aid in identifying inefficiencies and potential for savings in respect of resources. Sankey diagrams can also be used to map value flows in systems at the operational level or along global value chains [23].

An important aspect of proper functioning of companies is well organized internal transport influencing optimum material flow and minimization of the costs involved in it. Transport of materials includes relocation, packing and storage of materials in various forms within a single company. Organization of material transport results from the function and goals of the given company. It is not only the issue of internal relations that is considered when organizing material transport - the organization must also be open to outer links. Most logistic systems have high requirements. The requirements must be approved and realized by the individual units related to those systems [24].

The fundamental goal of production logistics can be formulated as pursuance of the greatest delivery capability and reliability with the lowest possible logistic and production costs [25]. Its tasks, on the other hand, include organization, control and planning of the flow of raw materials, parts, cooperation elements, materials during the production process, starting from the supply warehouses, through the working stand and department storages to the ready product storing sites and sales. The tasks in the scope of material flow optimization in relation to logistics are of various character. Logistic processes are often unchanged since long ago. Many companies focus their attention, first of all, on production processes. Production areas are often organized without consideration of the logistic costs incurred by the existing production system. Those costs are removed or compressed. This results in the following faults: unorganized processes, lack of clear assignment of duties in the individual areas, long transport paths, overlapping flow lines, lack of predetermined traffic paths, unnecessary repacking processes, large material reserves in production sectors, lack of transparency of the staff working time, lack of transparency of the internal logistic cots and their division into parts [26]

The necessity to change the organization of material flow in a company should be determined by the result of the analysis of the current state of internal logistics. There are many reasons of optimization of the material stream, among others, modification of the company's requirements, seeking savings, necessity to determine the precise number of transport means, growing complexity of the logistic processes, restructuration and development of the firm. Material flow disturbances most often result from the utilized "technology" of internal logistics: who delivers the material to the production lines, what means he uses and how he does it. Another reason is problems in production planning.

Separation of material streams and, consequently, optimization of machine arrangement and flow paths, should result in an increase of the company effectiveness by achieving a number of advantages: (i) easier planning limited number of elements produced in each stream results in production planning being much simpler; easier control - results from the organization of the subject group of working stands and the supervisor can easily inspect the material flow and permanently control the current performance of production tasks; (ii) reduction of the time of a product passage though the production stream - as result of many factors: more effective planning and controlling, shorter time of transport between the stands due to their location close to each other, as well as shorter time of storage due to the lack of necessity to keep high storage states; (iii) minimization of the reserve to be kept - should be due to reorganization of storage buffers supplying the individual streams; also by better planning and shorter reserve renewal time [27]; (iv) determination and monitoring of material and energetic requirements related to economy maintenance and growth; (v) identification and assessment of trends in the size of rejection and the potential of preservation of resources and recycling; (vi) identification and monitoring of material wastes getting to the environment and assessment of their impact on the environment; (vii) monitoring the changing quantities of material resources in use, recycling and reutilization; (viii) responding to questions related to material demand and the possibility of material shortage in long term prospect [28].

The paper presents a proposal of material flow optimization in a production company of the automotive branch by creation of an internal transport program and a project of optimization of the working stands arrangement by the Bloch-Schmigalla method.

\section{The purpose, methodology and scope of investigation}

The enterprise under investigation is a production company offering composite elements for automotive industry, electric machines industry, agriculture industry and for a vast range of other industrial applications. It is specialized in short and medium production series. It manufactures products based on documentation supplied by the order and on its own documentation. The design 
department of the company conducts a project from the stage of initial design to the production implementation of the product. The company offers uncomplicated composite elements and complete modules of devices with high degree of complexity. The sequential just-intime system basing on EDI is applied.

The production activity of the company is performed in two departments: High-Performance Plastics and Automotive Plastics. The High-Performance Plastics Department works mostly for the energetic segment in the scope of composite elements used in the production of turbo generators. The Department of Automotive Plastics supplies composite elements for vehicles and machines. The company's products are used, among others, as vehicles, industrial machines and special products. The parts are made with the use of various techniques including vacuum thermoforming, all the technologies of processing laminates reinforced with glass fibre and PDCPD high pressure injection. The key composite elements are used in the production of turbo generators. The production program comprises technologically advanced support rings, air guides, fixing elements and insulation shields in any size and material requirements. The scope of application includes also building facilities and agriculture machines, elements for wheelchairs, pressure formed inserts for shoe producers and commercial playing fields. The company uses the technology of high pressure injection to form, among others, vehicle body parts, machine shielding elements and elements for building industry. The projects are realized in the under-one-roof system from the concept to dispatch thanks to the coordinated work of several departments: that of designing, that of processing, that of production and that of logistics.

The quality processes used in the organization are, among others, FMEA analysis, risk management, checking and repair (tools and parts), process audits, analysis of non-conformance $(8 \mathrm{D}, 5 \mathrm{~W})$, corrective and preventive actions in order to improve quality.

The purpose of the paper is an analysis of the current situation of the company and execution of a project of material flow in the company in the scope of manufacturing ABS element (driver's compartment) used in the automotive industry. The ABS material has various trades names, among others, Cycolac, Lustran, Magnum, Novodur, Polylac, Sinkral, Terluran.

The scope of the work includes elaboration of the components of the internal transport program:

- shipping unit chart,

- transport and storage chart,

- distribution of the flow intensity of shipping units,

- assembly of the points of dispatch and receipt,

- material flow diagram,

- cross table of material flow,

- Sankey diagram,

- material flow process charts,

- charts of transport cycles,

- project of optimization of the working stands arrangement by the Bloch-Schmigalla method.

\section{Current state and internal transport program}

The analysis of material flow during production of an ABS element has been performed in three stages:

- Recognition of the current state.

- Elaboration of the internal transport program.

- Analysis and optimization.

The division has made it possible to incorporate many factors significantly influencing the internal transport during manufacturing of a product.

\subsection{Analysis of the current state}

The first stage of the analysis was determination of the current situation and systematization of the input data. This process has been affected by the delivery of adequate data from the company and by the analysis performed basing on observation and questionnaire containing 27 questions for the assessment of internal transport and storage.

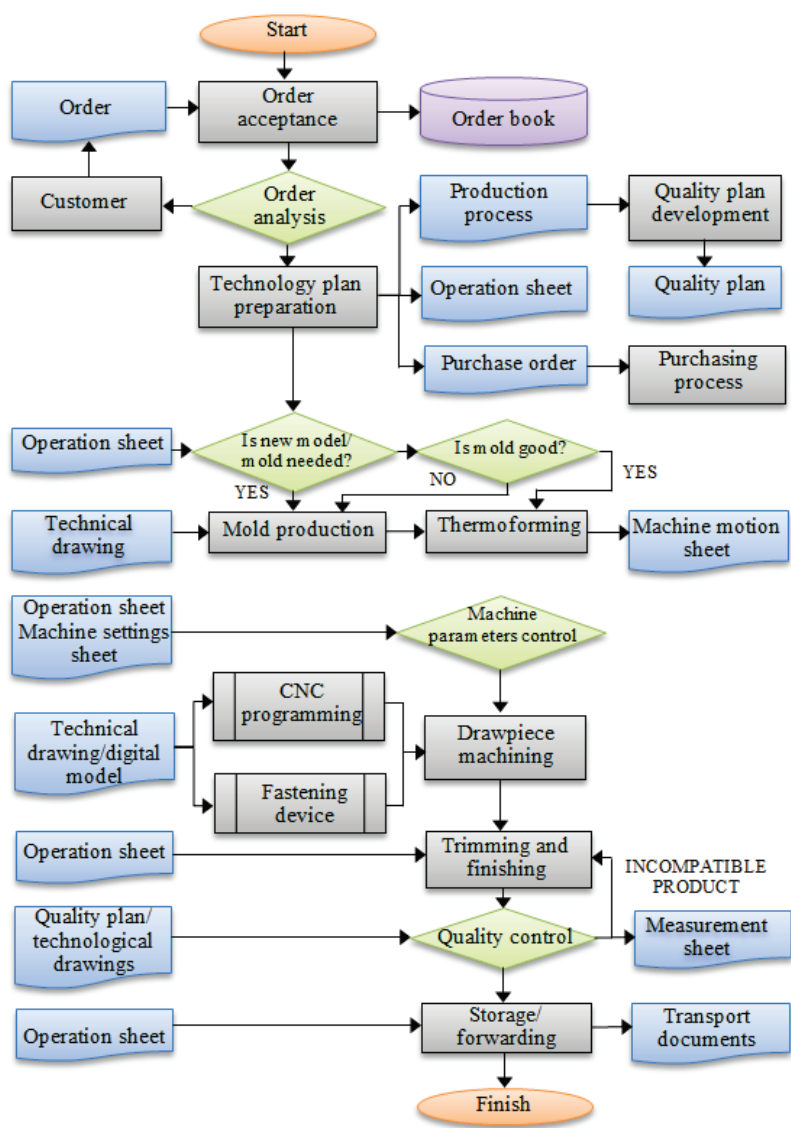

Figure 1 Map of the processes for manufacturing ABS products in the company

The input data necessary for the analysis concerned: analysis of the ready-made product and its components, properties of the ABS material,

- types and number of currently used means of transport,

- number of pallets at the input and at the output,

- arrangement of working stands in the production hall,

- determination of the transport tasks performed,

- determination of the major loading points, 
- determination of seasonality of orders,

- determination of day accumulations,

- determination of delivery/dispatch at defined times of day.

A map of the processes of manufacturing products of ABS in the company has also been elaborated (Fig. 1).

\subsection{Elaboration of the internal transport program}

In the second stage, the data acquired have been used to elaborate a detailed program of internal transport. The following documents have been elaborated:

- $\quad$ shipping unit chart,

- transport and storing chart,

- distribution of the intensity of shipping units flow at input in a year (Fig. 2),

- assembly of the points of dispatch and receipt (Tab. $1)$,

- materials flow diagram (Tab. 2),

- cross table of materials flow,

- Sankey diagram and the corresponding cross table (Fig. 3, Tab. 3),

- chart of materials flow process,

- chart of transport cycles (Tab. 4)

As a result, one got an idea of the transport paths along which the means of transport move in order to perform the tasks assigned to them. This has been a starting point for proper analysis and proposal of optimization.

In each material flow, the major factors are: the form, shape, size and design of the material being processed because they indicate which technological operations are necessary, what should be the sequence of operations and what paths of material flow should be adopted.

The program of transport is determined in the quantitative aspect and in the qualitative one. The principal information for the determination of the transport program is in the answers to the following six questions: what? (it is necessary to define the kind of material, its shape, dimensions, mass, packing unit, shipping unit) how much/how many? (it should be stated how many material units or shipping units are relocated, reloaded or stored, on the average and maximum in all the areas and on each path in the predetermined time) (for example, as in Tab. 4), from where? (the points of dispatch and receipt of the material should be marked on the company map in the form of the flow diagram and it should be stated what is delivered (see Tab. 1), where to? (how much/how many and where to/where from and at what time (see Tab. 4), how? (state in what way the material units, packing units or shipping units are relocated, reloaded and stored, what means of transport are applied, what is their number and how they are controlled, what number of people, with what qualifications, are necessary for the flow process to be effected) [29].The defined points of dispatch and receipt, with the distinction of the material input and output forms, for the production company under investigation are presented in Tab. 1.
Table 1 Dispatch and receipt points of ABS material

\begin{tabular}{|c|c|c|c|}
\hline \multirow{2}{*}{$\begin{array}{l}\text { Dispatch and receipt } \\
\text { points determination } \\
\text { (function, activity) }\end{array}$} & \multirow[b]{2}{*}{$\begin{array}{l}\text { Designation } \\
\text { of the point }\end{array}$} & \multicolumn{2}{|c|}{ Type of material and its form } \\
\hline & & $\begin{array}{l}\text { Delivered to } \\
\text { the point }\end{array}$ & $\begin{array}{c}\text { Coming out of } \\
\text { the point }\end{array}$ \\
\hline $\begin{array}{l}\text { Storage of pallet } \\
\text { shipping units }\end{array}$ & S1 & $\begin{array}{c}\text { Pallet } \\
\text { shipping units }\end{array}$ & $\begin{array}{l}\text { Pallet shipping } \\
\text { units }\end{array}$ \\
\hline Thermoforming & $\mathrm{T}$ & $\begin{array}{c}\text { Pallet } \\
\text { shipping units }\end{array}$ & $\begin{array}{c}\text { Semi-finished T } \\
\text { product }\end{array}$ \\
\hline CNC machining & $\mathrm{C}$ & $\begin{array}{l}\text { Semi-finished } \\
\text { T product }\end{array}$ & $\begin{array}{c}\text { Semi-finished C } \\
\text { product }\end{array}$ \\
\hline $\begin{array}{l}\text { Finishing and } \\
\text { assembly }\end{array}$ & FA & $\begin{array}{l}\text { Semi-finished } \\
\text { C product }\end{array}$ & $\begin{array}{c}\text { Finished } \\
\text { product/Waste } \\
\text { material }\end{array}$ \\
\hline Quality control & Q & $\begin{array}{l}\text { Finished } \\
\text { product }\end{array}$ & $\begin{array}{c}\text { Finished } \\
\text { product/Waste } \\
\text { material } \\
\end{array}$ \\
\hline $\begin{array}{l}\text { Temporary storage } \\
\text { before the } \mathrm{T} \text { point }\end{array}$ & B1 & $\begin{array}{c}\text { Pallet } \\
\text { shipping units }\end{array}$ & $\begin{array}{l}\text { Pallet shipping } \\
\text { units }\end{array}$ \\
\hline $\begin{array}{l}\text { Temporary storage } \\
\text { before the C point }\end{array}$ & B2 & $\begin{array}{l}\text { Semi-finished } \\
\mathrm{T} \text { product }\end{array}$ & $\begin{array}{c}\text { Semi-finished } \mathrm{T} \\
\text { product }\end{array}$ \\
\hline $\begin{array}{l}\text { Temporary storage } \\
\text { behind the } \mathrm{C} \text { point }\end{array}$ & B3 & $\begin{array}{l}\text { Semi-finished } \\
\mathrm{C} \text { product }\end{array}$ & $\begin{array}{c}\text { Semi-finished C } \\
\text { product }\end{array}$ \\
\hline $\begin{array}{l}\text { Temporary storage } \\
\text { before the Q point }\end{array}$ & B4 & $\begin{array}{l}\text { Semi-finished } \\
\mathrm{C} \text { product }\end{array}$ & $\begin{array}{l}\text { Semi-finished C } \\
\text { product }\end{array}$ \\
\hline $\begin{array}{l}\text { Temporary storage } \\
\text { behind the Q point }\end{array}$ & B5 & $\begin{array}{c}\text { Finished } \\
\text { product }\end{array}$ & Finished product \\
\hline $\begin{array}{l}\text { Waste material } \\
\text { storage }\end{array}$ & W & $\begin{array}{l}\text { Semi-finished } \\
\mathrm{T} / \mathrm{C} \text { product }\end{array}$ & $\begin{array}{c}\text { Incompatible } \\
\text { product }\end{array}$ \\
\hline $\begin{array}{l}\text { Storage of finished } \\
\text { products }\end{array}$ & S2 & $\begin{array}{c}\text { Finished } \\
\text { product }\end{array}$ & $\begin{array}{c}\text { Product for } \\
\text { shipment }\end{array}$ \\
\hline
\end{tabular}

Based on the data concerning orders in the individual months, distribution of the intensity of shipping units flow at input in a year has been elaborated, which can be seen in Fig. 2.

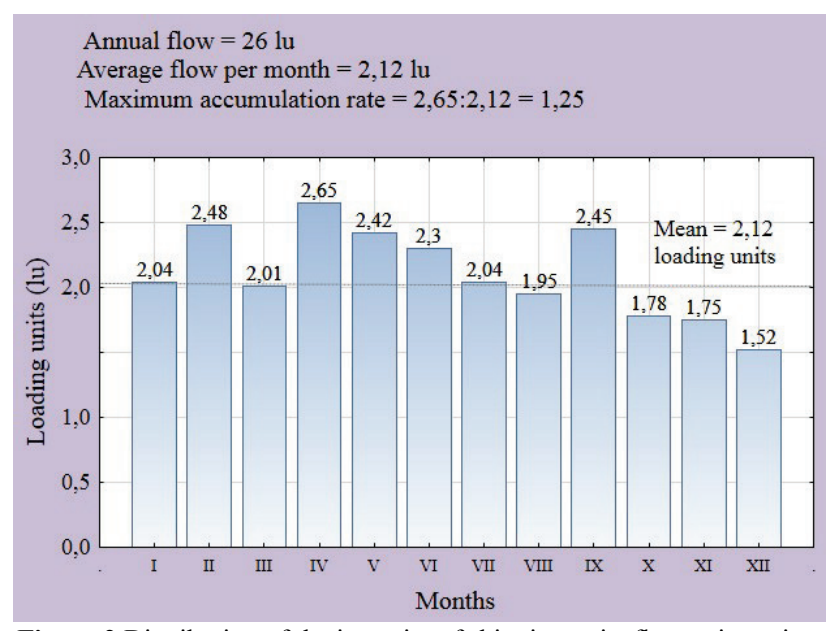

Figure 2 Distribution of the intensity of shipping units flow at input in a year

As one can see from Fig. 2, the maximum magnitude of supplies related to the average annual supplies was 1,25 of a shipping unit. This is a result of the small demand for frequent material deliveries due to the short production series of glove compartment. Low accumulation coefficient as compared to the average number of shipping units in a month has proved good organization and cooperation with the suppliers.

After determination of the dispatch and receipt points, detailed elaboration of the number of materials relocated from stand to stand has been made, which is shown in Tab. 2.

It has also been checked whether the number of materials intended for production is equal to that of the 
output materials. On that basis, flow balance has been determined. Data assembly in the form of a cross table, constituting a transfer of the information from the process sheet of the flow of materials in the company during one shift, has been used for that purpose. Sankey's graph diagram (Fig. 3) has also been elaborated, with the presentation of actual monthly flow sizes with the incorporation of the mass factor and transport relations.

Table 2 Process sheet of the flow of materials

\begin{tabular}{|c|c|c|c|c|}
\hline \multicolumn{2}{|c|}{$\begin{array}{l}\text { Entrance to the point } \\
\text { Number of accepted units }\end{array}$} & \multirow{2}{*}{$\begin{array}{l}\text { Dispatch } \\
\text { and/or } \\
\text { receipt } \\
\text { points }\end{array}$} & \multicolumn{2}{|c|}{$\begin{array}{c}\text { Exit from the point } \\
\text { Number of released units }\end{array}$} \\
\hline $\begin{array}{l}\text { From particular } \\
\text { points }\end{array}$ & Total & & Total & $\begin{array}{l}\text { To particular } \\
\text { points }\end{array}$ \\
\hline- & - & S1 & 21 & (B1)21 \\
\hline (S1)21 & 21 & B1 & 21 & (T)18 (FA)3 \\
\hline (B1)18 & 18 & $\mathrm{~T}$ & 18 & (B2)18 \\
\hline (T) 18 & 18 & B2 & 18 & (C)14 (W)4 \\
\hline (B2)14 & 14 & $\mathrm{C}$ & 14 & (B3)14 \\
\hline (C) 14 & 14 & B3 & 14 & (B4)10 (W)4 \\
\hline (B3)10 & 10 & B4 & 10 & (FA) 10 \\
\hline (B1)3 (B4)10 (Q)4 & 17 & FA & 17 & (B5)13 (W)4 \\
\hline (FA)13 & 13 & B5 & 12 & (S2)9 (W)4 \\
\hline (FA)4 & 4 & $\mathrm{Q}$ & 4 & (FA)4 \\
\hline (B2)4 (B3)4 (B5)4 & 12 & $\mathrm{~W}$ & - & - \\
\hline (B5)9 & 9 & $\mathrm{~S} 2$ & - & - \\
\hline
\end{tabular}

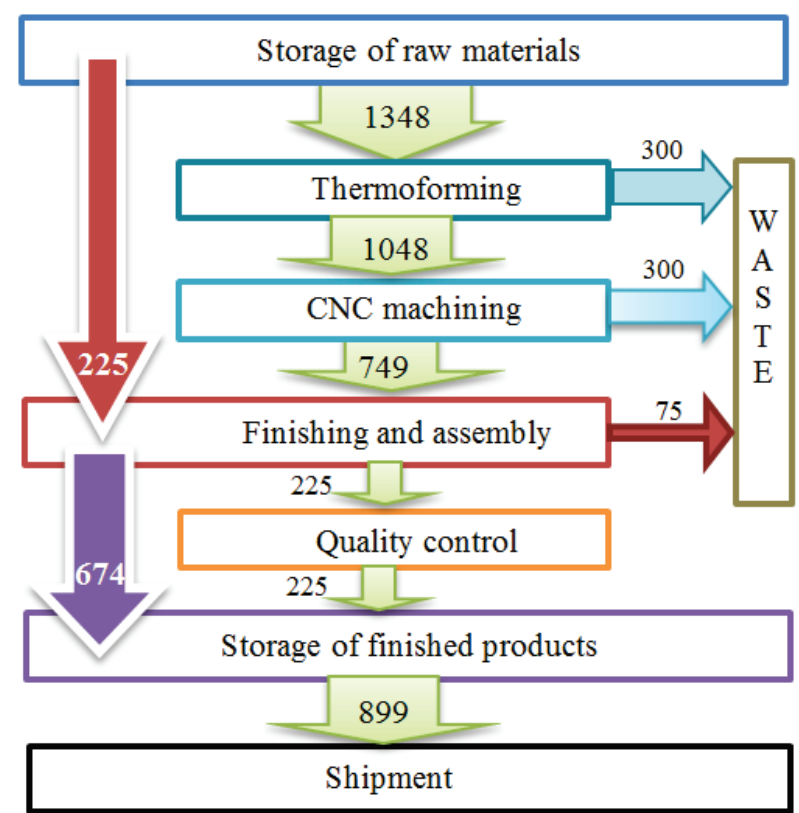

Figure 3 Sankey's graph diagram of materials flow on a monthly basis $(\mathrm{kg})$

Table 3 Monthly cross table of the material flow (kg)

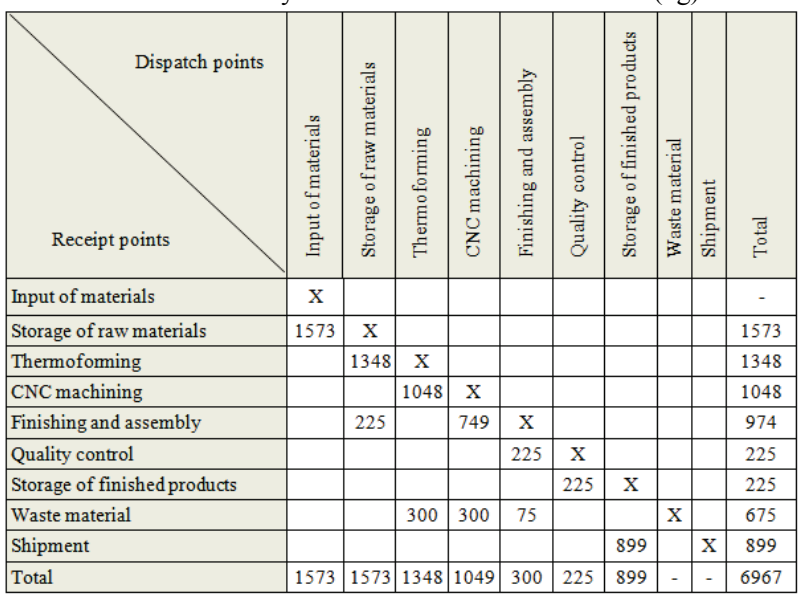

A month period of time has been adopted due to the fact of single material delivery in a month. In the individual boxes of the cross table (Tab. 3), the magnitudes of the monthly flows from the points of dispatch to the points of receipt have been stated.

Based on the elaborated graph of material flow, a process sheet of the flow of materials in the company has been created followed by the creation of a sheet of transport cycles (Tab. 4).

Table 4 Transport cycles card

\begin{tabular}{|c|c|c|c|c|c|c|c|c|}
\hline \multicolumn{9}{|c|}{$\begin{array}{l}\text { The starting point of the process: the car at the entrance } \\
\text { The end point of the process: the car at the output }\end{array}$} \\
\hline \multirow{2}{*}{$\begin{array}{c}\text { Cycle } \\
\text { no }\end{array}$} & \multirow{2}{*}{$\begin{array}{c}\text { Distance } \\
{[\mathrm{m}]}\end{array}$} & \multicolumn{4}{|c|}{ Symbols of the process } & \multirow{2}{*}{\begin{tabular}{|c|}
$\begin{array}{c}\text { Number } \\
\text { of cycles } \\
\text { in a } \\
\text { month }\end{array}$ \\
\end{tabular}} & \multirow{2}{*}{\begin{tabular}{|c|} 
Cycle \\
time \\
{$[\mathrm{h}]$}
\end{tabular}} & \multirow{2}{*}{$\begin{array}{c}\text { Time } \\
\text { total } \\
{[\mathrm{h}]}\end{array}$} \\
\hline & & \begin{tabular}{c|} 
What \\
$?$
\end{tabular} & $\begin{array}{c}\text { From } \\
\text { where } \\
?\end{array}$ & How? & \begin{tabular}{|c|} 
To \\
where \\
$?$ \\
\end{tabular} & & & \\
\hline 1 & 2 & $\square$ & $\perp$ & $9_{2}$ & psu & 48 & 0,015 & 0,72 \\
\hline 2 & 55 & psu & $\perp$ & L & $\nabla$ & 2 & 0,083 & 0,167 \\
\hline 3 & 2 & $\square$ & psu & $\mathrm{P}_{2}$ & cpsu| & 46 & 0,008 & 0,383 \\
\hline 4 & 40 & cpsul & $\nabla$ & L & $\smile_{1}$ & 23 & 0,083 & 1,917 \\
\hline 5 & 2 & $\mathrm{M}$ & $\square_{1}$ & 9 & $O$ & 414 & 0,007 & 2,76 \\
\hline 6 & 50 & cpsul & $\square_{1}$ & $T$ & $\bigcirc_{4}$ & 23 & 0,167 & 3,833 \\
\hline 7 & 3 & $\mathrm{C}$ & $\mathrm{O}$ & 9 & $\square_{2}$ & 667 & 0,006 & 3,669 \\
\hline 8 & 4 & $\mathrm{C}$ & $\square_{2}$ & 9 & $\mathrm{O}$ & 529 & 0,017 & 8,817 \\
\hline 9 & 3 & $\mathrm{C}$ & O & 9 & $\square_{3}$ & 529 & 0,010 & 5,290 \\
\hline 10 & 41 & $\sqrt{4}$ & $\square_{3}$ & $T$ & $\bigcirc_{4}$ & 23 & 0,117 & 2,683 \\
\hline 11 & 41 & 56 & $\square_{3}$ & $T$ & $\square_{4}$ & 23 & 0,117 & 2,683 \\
\hline 12 & 41 & $\mathrm{C}$ & $\square_{3}$ & 9 & $\square_{4}$ & 23 & 0,117 & 2,683 \\
\hline 13 & 3 & C 6 & $\square_{4}$ & 9 & 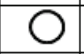 & 368 & 0,012 & 4,293 \\
\hline 14 & 48 & $P$ & 0 & P & $\square$ & 23 & 0,133 & 3,067 \\
\hline 15 & 48 & $P$ & $\square$ & 9 & O & 23 & 0,133 & 3,067 \\
\hline 16 & 3 & PW & $\bigcirc$ & P & $\square_{5}$ & 92 & 0,042 & 3,833 \\
\hline 17 & 50 & $\sqrt{31}$ & $\square_{5}$ & L & $\nabla$ & 23 & 0,167 & 3,833 \\
\hline 18 & 2 & $\mathrm{P}$ & \begin{tabular}{|l|}
3 \\
\end{tabular} & 9 & $\nabla$ & 69 & 0,025 & 1,725 \\
\hline 19 & 41 & $\mathrm{P}_{2}$ & $\nabla$ & $9_{2}$ & $\sqcup$ & 10 & 0,092 & 0,917 \\
\hline 20 & 55 & $\mid$\begin{tabular}{l|}
2 \\
\end{tabular} & $\mathrm{RP}$ & L & $\perp$ & 5 & 0,083 & 0,417 \\
\hline & $\begin{array}{l}\text { The sum } \\
=0,7[\mathrm{~h} / \\
1,7[\mathrm{~h} / \mathrm{d}\end{array}$ & he wo & & & & 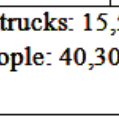 & $\begin{array}{l}3[\mathrm{~h}] \\
\mathrm{h}]=\end{array}$ & \\
\hline
\end{tabular}

\begin{tabular}{|c|l|l|l|}
\hline \multicolumn{4}{|l|}{ Explanation of symbols } \\
\hline$\square$ & cardboard & $\bigcirc$ & operation \\
\hline$\perp$ & car & $\mathrm{C} \mathrm{C}_{6}$ & component, 6 components \\
\hline \hline $9_{2}$ & $\begin{array}{l}\text { lemployee, two } \\
\text { employees }\end{array}$ & $\Gamma \mathrm{n}$ & $\begin{array}{l}\text { palette of } n \text { components } \\
\text { (n=2,3,4,6) }\end{array}$ \\
\hline \hline psu & pallet shipping units & $\square$ & control \\
\hline $\mathrm{L}$ & forklift truck & $\mathrm{P}$ & finished product \\
\hline$\nabla$ & storage & $\mathrm{PW}$ & finished product + waste \\
\hline cpsul & $\begin{array}{l}\text { complete pallet } \\
\text { shipping units }\end{array}$ & $\mathrm{L}$ & container \\
\hline$\square_{\mathrm{n}}$ & $\begin{array}{l}\text { waiting (position } \\
n=1,2,3,4,5)\end{array}$ & $\mathrm{RP}$ & reforming pallets position \\
\hline $\mathrm{M}$ & material unit & $\mathrm{T}$ & manual platform \\
\hline
\end{tabular}

In order to determine the times of work for the individual transport tasks, the whole material flow (from the delivery to the product loading on a truck) has been 
divided into transport cycles. Thanks to that, it was also possible to determine the repeatability of a given cycle and, on that basis, to calculate the time of a single task. Basing on this, the sum of the work of carriages and the sum of the work of personnel participating in the internal transport have been determined (see Tab. 4).

\section{Optimization of the internal transport program}

On the basis of the results obtained, an analysis in respect of the possibility of optimization has been performed. The analysis was focused mainly on the spatial arrangement of the working stands, determination of the internal transport means and the transport tasks. The suitability of the devices applied for the tasks performed and load of labour has been verified. This involved consideration of the necessity to use different types of carriages, unification of them or application of facilities improving the speed of transport cycles and work quality. The fluency of transport processes was significantly influenced by the transport tasks. The possibility of adequate integration of them has been considered.

Based on the analysis of the elaborated program of internal transport in the company, observation and conversations with the employees, physical flow of materials and parts has been recorded. The assessment of the obtained results has shown the potential of savings in the field of flow. It would be possible thanks to reorganization of the working stands or application of other means of transport within the individual zones. Based on the responses from the auxiliary check list, an analysis in respect of optimization possibility has been performed.

Analysis of the problems elaborated on the basis of the check list has shown the major problems in the following areas:

1) Time devoted to material handling to and from a machine by qualified employees.

Devotion of time for material handling to and from a machine by qualified employees, however, was a requirement which could not be minimized. Automation of the process of thermoforming is not possible due to the variety of products made on the thermoforming machine.

2) Frequent production breaks due to incorrect organization of material delivery and receipt to and from the stands.

This involved mainly the assembling department which could not go on working on a product unless all the required sub-assemblies have been delivered. The employees of the assembling department often personally supplied the missing elements and, consequently, contributed to the breaks in the process of assembling. It has been found that the time necessary for the transport of elements from the CNC stand to the far assembling stand could be minimized if semi products were supplied by the staff of the warehouse.

3) Shipping units not applied during transport and storage.

In this case, too, malfunctions occurred in the field of transport of elements by the staff of the assembling department who had to carry a part of the elements in their hands. This transport should be done with the use of means of transport, which would reduce the load of labour of a direct production employee. It should also be emphasized that the staff of the department of processing and assembling consisted of women for whom the admissible mass of loads lifted and carried are lower than for men. Improvement of safety in manual transport works consists, first of all in elimination of those works. Manual transport works means any kind of transporting, supporting of loads or materials by one or more employees including relocating them by: lifting, elevating, stapling, pushing, pulling, carrying, shifting, rolling or moving by carriages. Manual relocation of weights can cause sudden injuries, e.g. bone breaking, hurts, vertebral column injuries resulting from continuous execution of the operations of relocating weights, characterized by gradual progressing deterioration of the muscular-skeleton system. For the sake of safety and health protection of the staff employed in manual transport works, the employer should do his best to reduce the range of manual transport operations in his enterprise.

4) "Empty" operation of the company internal transport means for a period longer than $20 \%$ of the working time.

Another possibility of optimizing the work of forklift trucks has been noticed when material was transported with load in one direction only. It was particularly apparent in the $10^{\text {th }}$ and $11^{\text {th }}$ transport cycle. The company has an irregular system of internal transport because one transport facility, e.g. a fork lift, does not carry the material between two points only. Due to short production series, transport of goods is not constant and even. During transport, one of the travels is often an empty one. In such a case, the full cycle is loaded only $50 \%$. Relocation of the means of transport takes place, but without any goods transported. This is not an optimum and economically justified activity. That is why one should aim at travelling with load in the whole cycle.

5) Operation of internal transport means with small quantity of material carried by forklift trucks.

Carrying of small quantities of materials by a forklift truck was performed each time when delivering 3 ABS plates from stand B1 to B4. The transport was necessary due to the dimensions of the plates and big distance of stand B4. Location of the two stands close to each other has been recommended. This will eliminate long distance travels of the forklift trucks with small quantity of material carried and "empty" returns.

6) Existence of many reloading points on the production line.

Many reloading points resulted in the necessity to perform more transport operations, as well as time losses.

7) Too many transport operations performed.

It has been found that less transport operations could suffice to provide each working stand with materials necessary for production.

8) Coincidence of material flow lines.

Based on the elaborated diagram of material flow, it has been found that the lines of the individual flows coincide. Inadequate location of working stands results in the occurrence of returns. In this case, too, the best solution would be reorganization of the working stands so as to make the material flow linear. 
9) Execution of many unnecessary operations of material handling transport.

On the basis of elaborated documents concerning transport operations, it has been found that transferring ready-made products to the distant inspection department was a completely unnecessary operation. Modification of the working stands arrangement has been suggested and the inspection department employee has been asked to check the product conformance without transporting it to the inspection department. An argument in favour of the solution was the fact that it was not necessary to use the specialist facilities of the department.

10) Differences in delivery time depending on the working personnel (undefined responsibility).

Non-conformance has also been observed in the delivery times of elements to the department of processing and assembling. This was mainly due to the necessity of driving the forklift truck by an employee on foot. What is more, it was not precisely stated which of the staff members are responsible for the transport of elements. This led to rotation of responsibility.

\subsection{Analysis of material flow distance and quantity}

Considering subjective assessment of the necessity to correct the arrangement of the working stands, a decision has been made to perform an analysis. The analysis consisted in demonstration of the relationship between the quantity of material transported in a single transport cycle and the distance to which the material has been relocated. Based on the chart of transport cycles, the analysis of the dependence of the distance on the quantity of materials transported in a day has been performed; the analysis has been presented in Fig. 4.

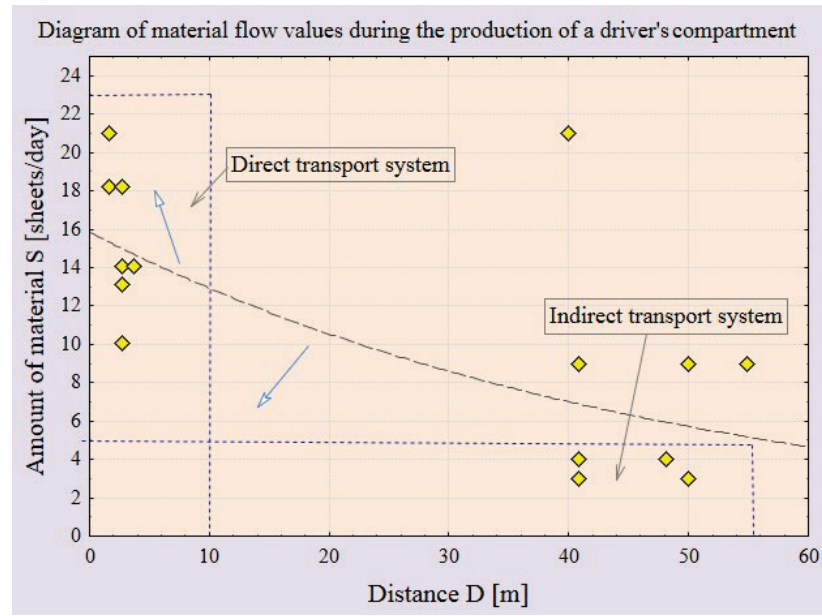

Figure 4 Diagram of material flow values during the production of a driver's glove compartment

The trend line shown in the diagram should be curved towards the origin of coordinates. This would define material flows as well located between the individual stands. In the elaboration of the dependence of the material flow on the distance in the enterprise, it has been found for the case of the glove compartment that, first of all, the location of working stands in the production hall should be corrected. It would allow for more effective utilization of the means of transport and for saving the working time of directly productive staff. In the case of short distances, direct transport should be applied (without the operations of loading and unloading) with the use of, e.g. a conveyor or tape. In the case of long distances, on the other hand, indirect transport, like a forklift truck, should be applied.

It has also been proposed to focus on maximization of material mobility by relocation without reloading, which has been shown in Tab. 5 .

Table 5 Rationalization of reloading activities depending on the way of storing

\begin{tabular}{|c|c|c|c|c|c|c|c|}
\hline $\begin{array}{l}\text { The method } \\
\text { of storage }\end{array}$ & 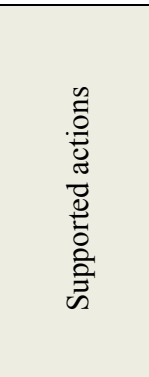 & 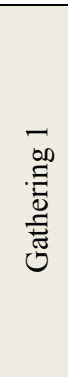 & 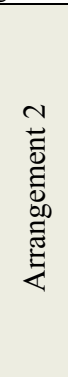 & 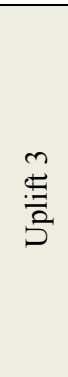 & 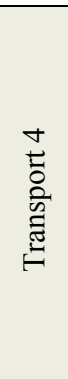 & 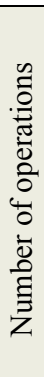 & 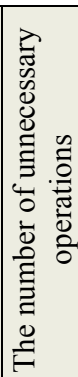 \\
\hline Loose & $1,2,3,4$ & Yes & Yes & Yes & Yes & 4 & 0 \\
\hline In container & $2,3,4$ & No & Yes & Yes & Yes & 3 & 1 \\
\hline On stands & 3,4 & No & No & Yes & Yes & 2 & 2 \\
\hline On the trolley & 4 (pulling) & No & No & No & No & 1 & 3 \\
\hline In motion & 0 & No & No & No & No & 0 & 4 \\
\hline
\end{tabular}

Based on observation and staff interviews, in this field, too, another way of flow facilitation has been found. Improvement of material mobility in transport between stands B3 and B4 has been proposed. Thanks to the use of containers in which a larger number of elements could be placed, three additional transport cycles can be eliminated (cycles 10, 11, 12). Additional utilization of a forklift truck will allow for reduction of men's working time in transport cycles. The solution will relieve an employee of the department of processing and assembling. Optimization of material flow to make it travel faster through the factory has also meant a reduction of the batch sizes. This would allow for reduction of the works in progress.

\subsection{Project of optimization of working stands arrangement}

The conclusion from the analysis of the current situation in the enterprise has become a starting point for the elaboration of the working stands arrangement determining the optimum state of flows. Unlike in the present state, the starting point was constant productivity. As the optimum variant, a new concept of the working stands arrangement and, consequently, material flow, has been elaborated according to the final scheme in the method of triangular network. In order to apply the method of triangular network, the cross table has been transformed into undirected one. Optimization of the working stands arrangement has been performed based on the method of Bloch-Schmigalla. The method of spatial organizing of the working site can be traced back to the nineteen fifties of the $20^{\text {th }}$ century. Bloch has used equilateral triangles seeking optimum working stands arrangement in a production system and in office administration one. The method has been developed by Schmigalla. The method assumes that the working stands are in an optimum arrangement when factor $W$ has the 
least possible value. The $W$ factor itself is a product of the size and relocation of a selected distance of a selected object, e.g. semi product, piece of information, employees. The least possible value means that the working stands are located in a way which ensures optimum flow without reduction of their productivity. For example, too close location of stands could limit the employees' possibilities or reduce their productivity; too far location, on the other hand, would extend the time of communication, relocation of employees or resources between the stands, additionally wasting the space of the enterprise or office [30]. Application of the method starts with determination of the number of working stands, relations between them and the sequence of locating them in the network of triangles. When introducing the BlochSchmigalla method, an algorithm of object dislocation is used. The first step of the algorithm consists in selection of a pair of objects with the largest intensity of flows in the table of the relations between objects. If there are more than one such pair, the one having the highest number of connections with the other objects is selected. If there is still more than one such pair of objects, a random pair is to be selected and placed in the neighbouring vertices of the central equilateral triangle of the network. Next, the sum of the intensity of connections between dislocated and not dislocated objects is determined. From among the not dislocated objects, the one having the highest intensity of connections with the dislocated objects is selected. If in this case, too, it turns out that there are more than one object with the same highest number of connections with the dislocated objects, a random one is selected. After selection of the subsequent object to be located, its potential position in the triangular network is determined [31]. Proper utilization of the method allows for optimization of the stands in possession. It can also be used in designing the still unused space.

Its major advantage is simplicity and limitation of organizational processes planning. It also requires a thorough analysis of the flow of resources and information, as well as the communication systems of the enterprise. It also utilizes a simplified model which assumes that all the stands occupy the same space. It does not take into consideration processes of modernization in the company or utilization of the limited space. In actual practice, the existing working stands are rebuilt or extended or located in currently free places [30].

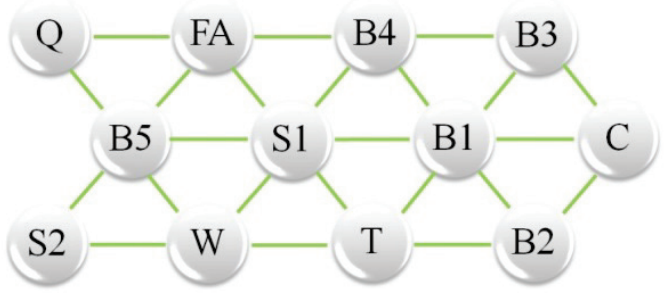

Figure 5 The proposal of material flow optimization by adequate dislocation of working stands: Q - Quality control; FA - Finishing and assembly; B1 - Temporary storage before the T point; B2 - Temporary storage before the $\mathrm{C}$ point; $\mathrm{B} 3$ - Temporary storage behind the $\mathrm{C}$ point;

B4 - Temporary storage before the Q point; B5 - Temporary storage behind the Q point; S1 - Storage of pallet shipping units; S2 - Storage of finished products; $\mathrm{T}$ - Thermoforming; $\mathrm{C}$ - CNC machining; $\mathrm{W}$ - Waste material storage
Based on the optimization performed, a project of the working stands dislocation has been created to ensure rationalization of material flow in the enterprise, as well as better utilization of the means of transport and employees. The optimization procedure has been performed in stages and the final results can be seen in Fig. 5.

\section{Conclusions}

Analysis of the internal logistics of the company under consideration has shown large potential of production optimization in respect of material flow and, consequently, minimization of the costs involved in it. The elaborated documentation of the program of internal transport and the project of material flow optimization by adequate dislocation of the working stands participating in the internal transport by the Bloch-Schmigalla method have enabled the product manufacturing cost to be reduced. The elaborated documentation of the internal transport program, i.e. shipping unit chart, transport and storage chart, distribution of shipping units flow intensity at input in a year, list of the points of dispatch and receipt, material flow diagram, cross table of material flow, Sankey diagram, material flow process chart, transport cycles chart have shown the possibility of rationalization of the process of manufacturing glove compartment and has revealed a number of significant problems. The problems were as follows: Frequent production breaks as result of incorrect organization of material delivery and receipt to/from the stands, lack of application of shipping units in transport and storage, much manual transport work assigned to women employed in the assembling department, "empty" work of internal means of transport ( $50 \%$ of load during one cycle) for a period longer than $20 \%$ of the working time, operation of the internal transport means with small quantities of materials by forklift trucks, existence of many reloading points in the production line, too many transport operations, coincidence of material flow lines, performing many unnecessary operations of material handling and transport, as well as differences in delivery time depending on the working personnel (undefined responsibility).

A number of rationalizing actions and modifications in the production process have been proposed for the sake of safety and health protection of the staff employed in manual transport works. The employer should do his best to reduce the scope of manual transport works in the enterprise: location of stands B1 and B4 close to each other has been recommended in order to eliminate long distance travels of forklift trucks with small quantity of material carried and returns with no load; application of the shipping unit during transport of elements between the milling stand and the department of machining and assembling has also been recommended, as well as integrated transport tasks in the transport cycles between the stand of temporary semi product storage before the $\mathrm{CNC}$ machining stand and the stand of temporary semi product storage after the $\mathrm{CNC}$ machining stand.

Reorganisation of the working stands in accordance with the project of material flow optimization by adequate dislocation of the stands participating in the internal 
transport by the Bloch-Schmigalla method will contribute to the reduction of the number of transport operations. It will ensure linearity of material feeding and transport.

\section{References}

[1] Krolczyk, G.; Legutko, S.; Krolczyk, J.; Tama, E. Materials Flow Analysis in the Production Process-Case Study. // Applied Mechanics and Materials. 474(2014), pp. 97-102. DOI: 10.4028/www.scientific.net/AMM.474.97

[2] Starbek, M.; Menart, D. The optimization of material flow in production. // International Journal of Machine Tools and Manufacture. 40, 9(2000), pp. 1299-1310. DOI: 10.1016/S0890-6955(99)00126-1

[3] DeGarmo, E. P.; Black, J. T.; Kohser, R. A. DeGarmo's materials and processes in manufacturing. John Wiley \& Sons Inc. 2011.

[4] Wolman, A. The metabolism of cities. // Scientific American. 213, 3(1965), pp. 179-190. DOl: 10.1038/scientificamerican0965-178

[5] Brunner, P. H.; Baccini, P. Regional material management and environmental protection. // Waste management \& research. 10, 2 (1992), pp. 203-212. DOI: 10.1177/0734242X9201000208

[6] Bergback, B.; Anderberg, S.; Lohm, U. Accumulated environmental impact: the case of cadmium in Sweden. // Science of the Total Environment. 145, 1(1994), pp. 13-28. DOI: 10.1016/0048-9697(94)90295-X

[7] Agnetis, A.; Pacifici, A.; Rossi, F.; Lucertini, M.; Nicoletti, S.; Nicolo, F.; Oriolo, G.; Pacciarelli D.; Pesaro, E. Scheduling of flexible flow lines in an automobile assembly plant. // European Journal of Operational Research. 97, 2(1997), pp. 348-362. DOI: 10.1016/S0377-2217(96)00203-2

[8] Chertow, M. R. Industrial symbiosis: literature and taxonomy. // Annual review of energy and the environment. 25, 1(2000), pp. 313-337. DOI: 10.1146/annurev.energy.25.1.313

[9] Sterr, T.; Ott, T. The industrial region as a promising unit for eco-industrial development - Reflections, practical experience and establishment of innovative instruments to support industrial ecology. // Journal of Cleaner Production. 12, 8(2004), pp. 947-965. DOI: 10.1016/j.jclepro.2004.02.029

[10] Wang, P. C.; Lee, Y. M.; Chen, C. Y. Estimation of resource productivity and efficiency: An extended evaluation of sustainability related to material flow. // Sustainability (Switzerland). 6, 9 (2014), pp. 6070-6087. DOI: 10.3390/su6096070

[11] Fuse, M.; Tsunemi, K. Assessment of the effects of the Japanese shift to lead-free solders and its impact on material substitution and environmental emissions by a dynamic material flow analysis. // Science of the Total Environment, 438 (2012), pp. 49-58. DOI: 10.1016/j.scitotenv.2012.08.017

[12] Teresa Torres, M.; Carmen Barros, M.; Bello, P. M.; Casares, J. J.; Miguel Rodríguez-Blas, J. Energy and material flow analysis: Application to the storage stage of clay in the roof-tile manufacture. // Energy. 33, 6(2008), pp. 963-973. DOI: 10.1016/j.energy.2007.09.008

[13] Hu, C. Q.; Zhang, C. X.; Han, X. W.; Yin, R. Y. Sulphur flow analysis for new generation steel manufacturing process. // Journal of Iron and Steel Research, International. 15, 4(2008), pp. 12-37. DOI: 10.1016/S1006-706X(08)60136-3

[14] Ohno, H.; Matsubae, K.; Nakajima, K.; Nakamura, S.; Nagasaka, T. Unintentional flow of alloying elements in steel during recycling of end-of-life vehicles. // Journal of Industrial Ecology. 18, 2(2014), pp. 242-253. DOI: 10.1111/jiec.12095

[15] Andersen, F. M.; Larsen, H.; Skovgaard, M.; Moll, S.; Isoard, S. A European model for waste and material flows.
// Resources, conservation and recycling. 49, 4(2007), pp. 421-435. DOI: 10.1016/j.resconrec.2006.05.011

[16] Mutha, N. H.; Patel, M.; Premnath, V. Plastics materials flow analysis for India. // Resources, conservation and recycling. $47,3(2006)$, pp. 222-244. DOl: 10.1016/j.resconrec.2005.09.003

[17] Itoiz, E. S.; Gasol, C. M.; Rieradevall, J.; Gabarrell, X. Methodology of supporting decision-making of waste management with MFA and CLCA: case study of waste paper recycling. // Journal of Cleaner Production. 2014. DOI: 10.1016/j.jclepro.2014.07.026

[18] Stanisavljevic, N.; Brunner, P. H. Combination of material flow analysis and substance flow analysis: A powerful approach for decision support in waste management. // Waste Management and Research. 32, 8(2014), pp. 733744. DOI: $10.1177 / 0734242 \times 14543552$

[19] Ghani, L. A.; Ali, N.; Mahmood, N. Z. A study of terengganu's biomass energy potential from forestry wastes via material flow analysis (MFA) approach. // Journal of Sustainability Science and Management. 9, 1(2014), pp. 120-127.

[20] Sendra, C.; Gabarrell, X.; Vicent, T. Material flow analysis adapted to an industrial area. // Journal of Cleaner Production. 15, 17(2007), pp. 1706-1715. DOI: 10.1016/j.jclepro.2006.08.019

[21] Claudia, R. Binder From material flow analysis to material flow management Part I: social sciences modeling approaches coupled to MFA. // Journal of Cleaner Production. $\quad 15, \quad$ (2007), pp. 1596-1604. DOI: 10.1016/j.jclepro.2006.08.006

[22] Brunner, P. H.; Rechberger, H. Practical handbook of material flow analysis. // The International Journal of Life Cycle Assessment. 9, 5(2004), pp. 337-338. DOl: 10.1007/BF02979426

[23] Schmidt, M. The Sankey diagram in energy and material flow management. // Journal of industrial ecology. 12, 1(2008), pp. 82-94. DOI: 10.1111/j.1530-9290.2008.00004.x

[24] Raczyk, R. The organization of materials handling in a distribution plant. // Transport Problems. 5 (2010), pp. 6570.

[25] Nyhuis, P.; Wiendahl, H. P. Fundamentals of production logistics. Theory, Tools and Applications, Berlin: SpringerVerlag, 2009. DOI: 10.1007/978-3-540-34211-3

[26] Beamon, B. M. Supply chain design and analysis: Models and methods. // International journal of production economics. 55, 3(1998), pp. 281-294. DOI: 10.1016/S09255273(98)00079-6

[27] Miszon, B.; Hadas, L.; Cyplik, P. Wydzielanie strumieni materiałowych jako koncepcja poprawy efektywności funkcjonowania przedsiębiorstwa produkcyjnego. // Logistyka. 5, (2011), pp. 7-10.

[28] Graedel, T. E.; Allenby, B. R. Industrial Ecology and Sustainable Engineering. International Edition. Pearson Education Inc., Upper Saddle River, Prentice Hall, 2010.

[29] Fijalkowski, J. Transport wewnętrzny w systemach logistycznych. Wybrane zagadnienia, Warszawa: Oficyna Wydawnicza Politechniki Warszawskiej, 2003.

[30] Schmigalla, H. Methoden zur optimalen Maschinenanordnung. Berlin: VEB Verlag Technik, 1969.

[31] Martyniak, Z. Metody organizacji i zarzadzania, Krakow: Wydawnictwo Akademii Ekonomicznej w Krakowie,1999.

\section{Authors' addresses}

Jolanta Krolczyk, PhD Eng.

Department of Biosystems Engineering

Opole University of Technology

76 Proszkowska Street, 45-758 Opole, Poland

E-mail: j.krolczyk@po.opole.pl 
Grzegorz, M. Krolczyk, PhD.

Opole University of Technology

76 Prószkowska Street, 45-758 Opole, Poland

E-mail: g.krolczyk@po.opole.pl

Stanislaw Legutko, Prof. DSc. PhD. Eng., Prof. h. c

Faculty of Mechanical Engineering and Management

Poznan University of Technology

3 Piotrowo Street, 60-965 Poznan, Poland

E-mail: stanislaw.legutko@put.poznan.pl

Jerzy Napiorkowski, Prof. DSc. PhD. Eng.

Department of Vehicle and Machine Construction and Operation

University of Warmia and Mazury,

11 Oczapowskiego Street, 10-719 Olsztyn, Poland

E-mail: napj@uwm.edu.pl

Sergej Hloch, Prof. DSc. PhD. Eng.

Faculty of Manufacturing Technologies

Technical Universtity of Košice with a seat in Prešov

Bayerova 1, 08001 Prešov, Slovak Republic

E-mail: hloch.sergej@gmail.com

Joachim Foltys, Prof. DSc. PhD. Eng.

Faculty of Economy and Management

Opole University of Technology,

76 Proszkowska St., 45-758 Opole, Poland

E-mail: j.foltys@po.opole.pl

Ewelina Tama, MSc. Eng.

Opole University of Technology

76 Prószkowska Street, 45-758 Opole, Poland

E-mail: ewelkat1988@wp.p 